\title{
Redrawing Relationalities at the Anthropocene(s): Disrupting and Dismantling the Colonial Logics of Shared Identity Through Thinking with Kim Tallbear
}

\author{
Priyanka Dutt, Anastasya Fateyeva, Michelle Gabereau, \\ and Marc Higgins
}

What does it mean to respond to the Anthropocenes, plural, when doing science education? As Davis and Todd (2016) query, "if the Anthropocene is already here, the question then becomes, what can we do with it as a conceptual apparatus that may serve to undermine the conditions that it names" (p. 763)? What is gained and what is lost through the rallying cry of the naming of this epoch after humankind (i.e., the Anthropos), particularly if and when such a naming of a shared catastrophe masks the uneven responsibility for this contemporary moment, as well as the unequal ways in

The original version of this chapter was revised: ESM has been updated. The correction to this chapter is available at https://doi.org/10.1007/978-3-030-79622-8_24

Supplementary Information The online version contains supplementary material available at (https://doi.org/10.1007/978-3-030-79622-8_7).

P. Dutt $(\varangle)$

University of Lethbridge, Lethbridge, AB, Canada e-mail: pdutt@ualberta.ca

A. Fateyeva

Edmonton Public Schools, Edmonton, AB, Canada

e-mail: fateyeva@ualberta.ca

M. Gabereau

Ehpewapahk Alternate School, Maskwacis, AB, Canada

e-mail: gabereau@ualberta.ca

M. Higgins

Department of Secondary Education, University of Alberta, Edmonton, AB, Canada e-mail: marcl@ualberta.ca

(C) The Author(s) 2022, corrected publication 2022 
which it is felt? More pointedly, can we critically engage with the Anthropocene, singular, without acknowledging the multiplicity of moments in which Indigenous Land and its ecology of humans, other-than-humans, and morethan-humans were at risk of extinction from "Man"? Within this chapter, we contend that if the ways of thinking and practicing both science and science education continue to be rooted in the same settler ${ }^{1}$ colonial, capitalist, and toxic ways-of-knowing and -being that have and continue to produce Indigenous erasure and support the acquisition of Indigenous Land, that responses to the Anthropocene, singular, will be fraught (e.g., Bang \& Marin, 2015; Liboiron et al., 2018). As Davis and Todd (2016) state:

without recognizing that from the beginning, the Anthropocene is a universalizing project, it serves to re-invisibilize the power of Eurocentric narratives, again re-placing them as the neutral and global perspective. By linking the Anthropocene with colonization, it draws attention to the violence at its core, and calls for the consideration of Indigenous philosophies and processes of Indigenous self-governance as a necessary political corrective, alongside the selfdetermination of other communities and societies violently impacted by the white supremacist, colonial, and capitalist logics instantiated in the origins of the Anthropocene. (2016, p. 763)

Beginning from the recognition that both science and science education are most often premised on othering Indigenous peoples (Bang \& Marin, 2015; Tallbear, 2013), we leverage this unusual turn towards $a$ shared identity as a means of provoking new ways for the Anthropocene(s) to be felt. In this work, we take seriously Davis and Todd's (2016) call for the "consideration of Indigenous philosophies and processes ... as necessary political corrective" by engaging in a citational politics: we privilege and think with Indigenous thought-practices that have been working within, against, and beyond Western humanism since the beginnings of colonization. Notably, we turn to Dakota scholar Kim Tallbear (2013), drawing on her work illuminating and troubling the relations between identity, science, settler colonialism, and Indigeneity. Following this, we offer a series of aesthetic provocations as a means of making the Anthropocene(s) felt otherwise.

\section{Troubling Shared Identity as a SeTtler Move to InNocence}

Western modern science, from its very beginnings, operationalizes processes through which some are deemed "non-scientific" as a means of legitimizing and lifting those that are "scientific." Such logics extend more broadly to Western modernity and through colonial logics: dichotomously framing some as having culture, civilization, knowledge, and rationality, amidst other things,

\footnotetext{
${ }^{1}$ Settler colonialism is a structure, and not only an event, through which settlers continue an ongoing project of Indigenous erasure and Land acquisition (see Tuck \& Yang, 2012).
} 
because others have not. While these culturally shape(d) who can and could participate in science, as well as how, it also affects the kinds of sciences practiced.

While the genetic science of race is largely discounted today, Tallbear (2013) reminds us that "gene discourses and scientific practices are entangled in ongoing colonialisms. What 'they' [settlers] think and do have always determined how much trouble 'we' [Native Americans] have" (p. 9). Despite science's distancing from race, we continue to see contemporary examples of how science is entangled in practices of defining, categorizing, policing, and perpetuating identities through practices such as direct-to-consumer DNA tests. In turn, science continues to inherit the responsibility to face the ways in which it has had and continues to have a part in defining identity, as well as how DNA continues to be systematically used to (re)direct power and privilege towards some (e.g., white settlers) at the expense of others (e.g., Indigenous peoples). For example, Tallbear (2013) invites us to consider the ways in which genetics is leveraged in the U.S. political system through property rights:

Property rights accorded to whiteness are protected by the U.S. legal system. One of those rights is control of the legal meanings of group identities. Whites have legally defined who counts as black or Indian. This is an important right, for the racialization and subordination of those black and red "others" has been necessary to solidify the exclusive parameters of whiteness. (TallBear, 2013, p. 136)

This difference has become so normalized and normative that white settlers can unironically approach the question of difference vis-à-vis a stance of "helping" Indigenous peoples without recognizing their own complicity: such as the colonial impulse to improve or introduce new technologies, framing traditional ways-of-knowing and -being as backwards. One such dubiously helpful techno-scientific extension is the genetic theory of the mitochondrial Eve, which would have us all originate from Africa, and the notion that if we could come to realize that we were all connected that racism would end: racism is incompatible with knowledge of genetics.

Challenging the notion that scientific knowledge is enough for change to occur, Tallbear (2013) reminds us that "racism does not need to be scientifically 'correct' to thrive. ... [It is an] ahistorical ... hope that scientific knowledge can make the crucial intervention of halting centuries of race oppression" (p. 149). As Tallbear (2013) suggests, it may not even be enough to halt racist and oppressive myths proffered by the same scientists who offer "we are all African" as corrective: genetic research on Indigenous peoples continues under the guise of "preserving" the DNA of "vanishing" Indigenous peoples. While it is beyond the scope of this chapter to fully unpack why this is problematic (e.g., not acknowledging the colonial complicities that accompany the production of the image of Indigenous peoples as vanishing, either culturally or physically), we are wary of what calls to shared identities make visible and what they mask in terms of colonial logics and practices. 
In turn, while we agree that we are all affected by and need to respond to the Anthropocene, we wish to attend to what the illumination of shared culpability serves to conceal. Since the 1950s, the period in which the Anthropocene is often stated to have begun, "carbon dioxide levels, mass extinctions, and the widespread use of petrochemicals, ... and radioactivity left from the detonation of atomic bombs" (Davis \& Todd, pp. 762-763) have been (re)shaping the globe. However, while we are all are impacted by and inherit the Anthropocene, it is irresponsible to frame the issue as one that impels and affects us all equally, as this serves to "mask power with innocence" (McKinley, 2001). The Anthropocene does not and cannot account for the ways that the responsibility for this current moment are unevenly distributed or how it unevenly impacts diverse groups: the Global South, endangered animals and species, Indigenous peoples, and marginalized urban and rural folk of colour, amidst others. Rather, not unlike Tallbear's (2013) lines of questioning of colonial complicities of genetic science, Tuck and Yang (2012) invite us to consider such actions as settler moves to innocence:

Settler moves to innocence are those strategies or positionings that attempt to relieve the settler of feelings of guilt or responsibility without giving up land or power or privilege, without having to change much at all. (p. 10)

Here particularly, the settler move to innocence is one of equivocation. Through equivocation, "or calling everything by the same name" (Tuck \& Yang, 2012, p. 17), the intent is to signal the ways in which we are all affected and must respond to this shared catastrophe. While not wholly untrue, equivocation serves to mask the ways in which settlers have conveniently ignored and have actively participated in Anthropocenes which precede and come to constitute the present one. For example, the "Orbis spike" of 1610 (Lewis \& Maslin, 2015) in which atmospheric $\mathrm{CO}_{2}$ levels drastically dropped as a result of the genocide of Indigenous peoples, having planetary consequences.

Further, Tallbear (2013) helps us to think about the ways in which colonial logics fetishize origins (e.g., the Anthropocene). Complicating the notion that Indigenous identity originates in DNA, Tallbear (2013) offers an Indigenous conception of being that is relational. Not only is such a means of honouring longstanding and ongoing Indigenous philosophies, but it is also a means of calling into question and understanding the ecology of settler colonial thought-practices which constitute problematic extractivist genetic practices through which Indigenous peoples continue to be the object of science. In turn, we believe that choosing to observe this Anthropocene (as the Anthropocene) has much to do with how the world's settlers have displaced and destroyed through extractivism (i.e., the production of "value" through ever accelerating extraction of resources). ${ }^{2}$

\footnotetext{
${ }^{2}$ It is also worth noting that even positive identity construction can also be in the service of settler colonial logics within. For example, Indigenous peoples who take up the
} 
After Davis and Todd (2016), we want to take seriously the notion that "the Anthropocene betrays itself in its name: in its reassertion of universality, it implicitly aligns itself with the colonial era" (Davis \& Todd, 2016, p. 763). However, rather than offer a corrective identifying (beyond the plural form: Anthropocenes), we turn to more relational forms of meaning-making in response to the ways in which $a$ meaning, like an identity, often works to reassert and reproduce settler colonial ways-of-knowing and -being. Specifically, we take seriously Tallbear's (2013) call to not make Indigenous peoples the object of study when discussing the manifestations of settler colonialism in science but rather invert the gaze back onto science itself. Further, an important move in not offering a corrective is that, as Plains Cree scholar Cash Ahenakew (2017) states, "the work of decolonization is not about what we do not imagine, but what we cannot imagine from our Western ways of knowing" (p. 88). We, as science educators, may need to sit with and in the difficult question of why we cannot or have not been able to respond to the Anthropocene(s). In turn, we recognize the need for new ways to (re)open what we can even imagine within science education as we respond to Anthropocenes. As Ahenakew states, "using metaphor and poetry to disrupt sense-making and prompt sense-sensing in the experience of readers" (2016, p. 337) because "modern academic literacies and technologies can make what has been made invisible by colonialism visibly absent, but they cannot make it present" (2017, p. 89). Accordingly, not only do we avoid offering the meaning because it risks reasserting and reproducing settler colonial ways-of-knowing and -being, but also because it may not be heard: science education has had and continues to have an active part in rendering unintelligible Indigenous ways-of-knowing and -being. Nonetheless, in endnotes, we offer $a$ meaning as a means of engaging the possibilities that the aesthetic provocations below make possible.

Below, you will find a series of image-texts ${ }^{3}$ that are intended to invite an unpacking and undermining of the problematic ways in which Indigeneity, settler colonialism, science education, and the Anthropocene(s) intersect and coalesce (e.g., producing non-Western epistemologies and ontologies as lesserthan). Inspired by diverse influences such as Indigenous storywork (e.g., Archibald, 2008), political cartoons, and meme culture we wish to produce a field of meaning-making that implicates the reader within the question of the Anthropocene(s) in the every day as well as its settler colonial and neo-colonial implications.

roles of Land protectors, while perpetually positioned as enemies of economic progress, are simultaneously positioned as stewards of the Land in ways that can and do let settlers off-the-hook in terms of their ecological responsibilities (El-Sherif, 2020).

${ }^{3}$ All of the following images have been illustrated by Anastasya Fateyeva. 


\section{Turtle Island: A Haudenosaunee Creation Story 4}

Long before the world was created, there was an island in the sky inhabited by sky people. One day, a pregnant sky woman drops through a hole created by an uprooted tree and begins to fall for what seems like eternity.

Coming out of darkness, she eventually sees oceans. The animals from this world congregate, trying to understand what they see in the sky. A flock of birds is sent to belp her. The birds catch her and gently guide her down onto the back of Great Turtle. The water animals like otter and beaver have prepared a place for her on turtle's back. They bring mud from the bottom of the ocean and place it on turtle's back until solid earth begins to form and increase in size.

Turtle's back becomes Sky Woman's home and the plants she brought down with her from Skyworld, including tobacco and strawberries, are her medicine. She makes a life for herself and becomes the mother of Haudenosannee life as we know it today.

\section{UNPACKING EverydAY (NeO-)COLONIALISMS ${ }^{5}$}

Let's talk about unpacking your recent purchase from Whiteazon. We can see that you're either in the pursuit of achieving a level of whiteness as defined and dictated by present-day, settler colonial society because you may not be white passing or perhaps you're educating yourself on the privileges that are associated with the notion of white passing and what that means. In the off chance that you're making this purchase as a white person, please leave a review when you can!

About:

\section{Colonialism Illustrated by Wyatt Mehn}

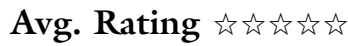

4 The first provocation is a depiction of Turtle Island, the name used by many Indigenous peoples when addressing what is colonially known as North America, followed by a Haudenosaunee creation story (Niro et al., 1999).

5 The second provocation is a satirical approach to the understandings of "belonging" in Western contemporary society. At once, it speaks to the requisite participation in consumeristic materialism: acquiring and holding valuable assets such as property, goods, and other forms of capital (which are then read as social capital). Simultaneously, it expresses a relation to whiteness and settler colonial logics: belonging often requires conformity of those not presenting in the image of MAN (e.g., changing or altering one's behaviour through speaking one language over another, changing the dress or traditional adornments one chooses to wear, etc.).

Further, this provocation also helps to exemplify the ways in which colonial science excludes contributions to the field of STEM from the East or from different origins. Finally, there is the notion of identity and what that means, how it is defined, and how we use said definitions to create laws. Of particular note here is the tendency to dictate identity based on direct-to-consumer DNA tests, which may be used to govern bodies, but may also be used as ways to validate (or invalidate) certain identities over others, or invalidate them altogether (TallBear, 2013). It also begs the question: does one need a quantitative measure to know their identity or can identity be rooted in something else altogether? 
Wyatt Mehn knows just how confusing colonialism can be. In his illustrative piece, Mehn attempts to depict the ways in which one can attain a colonial body short of bleaching one's skin. This can be done by "acting white." In this piece, Mehn shows examples of the colonized person, i.e., straightening otherwise naturally curly hair when it is on a brown body, reducing the number of cultural or traditional adornments worn by a brown body, or negating accents or heritage-related tonal changes in order to establish a "white" voice. Mehn also shows the converse for each example, highlighting the spectrum of which these dichotomies exist.

\section{Important White Men by Ano Therwy Atman}

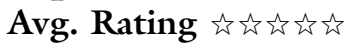

Perhaps you need to establish your place in a predominantly Eurocentric Western society. To do so, Atman has created a comprehensible guide to the Important White Men whose names replace the contributions from Eastern societies or from non-male bodies. From Watson and Crick's discovery of DNA and not Rosalind Franklin to the erasure of Ibn al-Haythem's contributions to the understanding of light and optics, this book will create space to understand and internalize the ways in which Eurocentrism and Western ideologies actively work against non-white, non-male bodies.

Property Management by Sam Guy

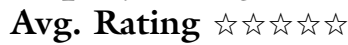

Owning property is a tough endeavour but Sam Guy has created a simple, multi-step approach that any person of colour can follow. In it, he speaks to the Five Fundamentals of Owning Property: Having means and money, Nepotism, Blankets laced with smallpox, Treaties that may or may not contain loopholes in which Indigenous peoples are tricked into giving up their livelihood for the sake of their nations, and general Whiteness. Guy's work also emphasizes that the fifth fundamental, whiteness, is perhaps the most precious and valuable property to have and hold in Western society.

Principles of Debate, Vol. 1-10 by Al SoSam Guy

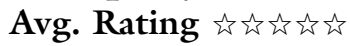

While the connections and sense of community we make on a day-to-day basis are valuable, $\mathrm{Al}$ Guy believes that the one true way to create identity is through the definitions posed by raw data or otherwise cultivated by science. In his inspiring collection of historical data and journal articles, Guy creates a map from genetic markers to the definitions and depictions of identity. No longer is a total of 7\% Japanese DNA markers irrelevant to your identity. Further, Guy provides explanations into the world of defining and labelling identity while also providing insights into what is or isn't part of those leading definitions, complete with an interview from presidential candidate Melizabeth Twarren and her embracing of her Cherokee DNA. 


\section{INDIGENOUS ERASURES: SUPERSESSIONISM and Scientific Origin Stories ${ }^{6}$}

Long before the world was created, there was an island in the sky inhabited by sky people. One day, a pregnant sky woman drops through a hole created by an uproeted tree and begins to fall for what seems like eternity.

Coming out of darkness, she eventually sees oceans. The animals from this world congregate, trying to understand what they see in the sky. A flock of birds is sent to help her. The birds catch her and gently guide her down ento the back of Great Turtle. The water animals like otter and beaver have prepared a place for her on turtle's back. They bring mud frem the bottem of the ocean and place it on turtle's back until selid earth begins to form and increase in size.

Turtle's back becomes Sky Woman's home and the plants she brought down with her from Skyorld, including tobaces and strawberries, are her medicine. She makes a life for herself and becomes the mother of Hatudenosaunee life as we know it today. (Niro et al., 1999).

When the solar system settled into its current layout about 4.5 billion years ago, Earth formed when gravity pulled swirling gas and dust in to become the third planet from the Sun. Like its fellow terrestrial planets, Earth has a central core, a rocky mantle, and a solid crust (NASA, 2020).

${ }^{6}$ The third provocation is a revisiting of the first, a newly rendered version of Turtle Island, but now with red pen and altered definitions. Following the previous "unpacking" of whiteness in settler colonial Western societies, we suggest that these settler colonial, Eurocentric, and strict views of science begin to produce particular ways-of-relating within and across places and communities. Specifically, we understand the project of "identity" and "origins" as being entangled in the production of hard and fast definitions which shape how the North and the rest of the global population is "mapped out" and understood. For example, the need to define a people: in the ability to quantify, by per cent, their DNA, or by the presence of haplogroups, or by the defined borders that we draw between societies, or by the hypotheses we create regarding a nation's potential migratory patterns (e.g., Bering land bridge theory). These ways-of-defining are inseparable from and entangled with settler colonial ideas of science and the larger project of Western modernity which desires the creation of lines and boundaries rather than bridges and connections between the self and the other, the observer and the observed, as a means of privileging settler colonial lifeways (e.g., lifting MAN, the subject of modernity, be they a scientist, educator, or other).

Within this provocation, the stark contrast between the Haudenosaunee creation story and NASA's explanation of the formation of the universe is included in order to truly show not only the dichotomy that exists within our present-day teachings of science and the stories by which Indigenous elders and other communities disseminate knowledge. It is also meant to invite a consideration of the way in which Western modern science supersedes other-ways-of-knowing and -being, erasing or devaluing them in the process. The question lingers: why does or must science education value one (Western modern science) so highly above all others? 


\section{Indigenous Erasures: The Genographic Project ${ }^{7}$}

The Genographic Project cannot, for example, tell me how I am related to my various Dakota tribal kin, the ultimate set of relations in tribal life. ... The question of how we as Dakota got to where we are has already been answered, and the answer does not lie in genetics. I could reference Dakota creation stories that give us values for living, narrate our common history, cohere us as a people with a common moral framework, and tie us to a sacred land base. ... "Who we really are" is not a question that most, if any, Dakota think can be answered by finding out that they have mtDNA markers that "originated" in Mongolia. (TallBear, 2013, p. 152)

\section{CONCLUSION}

The Anthropocene is the epoch under which "humanity"-but more accurately, petrochemical companies and those invested in and profiting from petrocapitalism and colonialism-have had such a large impact on the planet that radionuclides, coal, plutonium, plastic, concrete, genocide, and other markers are now visible in the geologic strata. (Davis \& Todd, 2016, p. 765)

The Anthropocene(s) are a time in which our present geological age is significantly defined by the impact of $\operatorname{Man}$ (e.g., the white, masculine subject of Western modernity). While the notion and framing of the Anthropocene is not wrong-increasing human influence has led to greater impacts on climate change and the surrounding ecosystems-we suggest that this admission of culpability masks more than it reveals: the Anthropocene cannot be separated from the scientific production of identity which upholds and reproduces settler colonial thought practices. Importantly, when 100 companies produce $71 \%$ of the world's pollution, the creation of a shared identity may divert attention away from addressing the "petrochemical companies and those invested in and profiting from petrocapitalism and colonialism” (Davis \& Todd, 2016, p. 765) who hold primary responsibility for the contemporary moment.

It is our desire that the above aesthetic provocations will generously generate different configurations of pedagogy which will allow for new ways to attend to the interconnected matrices of power and privilege which shape this contemporary Anthropocenic epoch that is predicated on so many

\footnotetext{
7 The fourth provocation illustrates the Manhattan plot: data that is extracted from a sample of one's DNA. Within a single sample, there may be dozens of genetic markers depicting dozens of differing identities within a single individual. However, as TallBear (2013) puts it, these tests cannot define who she is because her personhood emanates from her relations, rich culture, long-standing traditions, and passed down stories. Further, rather than a shared identity, TallBear (2013) speaks to how her Dakota kin are connected through their experiences, not by a direct-to-consumer DNA test that spits out an array of percentages based on genetic markers tied to Mongolia.
} 
other Anthropocenes. With this, we hope that these might allow for open, vulnerable, self-reflexive dialogue around the problematic ways in which the Anthropocene(s), Indigeneity, and science education intersect.

In refusing the ways in which we are discursively called to leave behind our relationalities in the universalizing project of the Anthropocene, we suggest turning to Indigenous thought-practices to break the cyclical storm of anthropogenic violence: to remember that the same land we begin to separate, colonize, commodify, and pollute is also the land in which we may find coalition and community.

\section{REFERENCES}

Ahenakew, C. (2016). Grafting Indigenous ways of knowing onto non-Indigenous ways of being. International Review of Qualitative Research, 9(3), 323-340.

Ahenakew, C. R. (2017). Mapping and complicating conversations about Indigenous education. Diaspora, Indigenous, and Minority Education, 11(2), 80-91.

Archibald, J. (2008). Indigenous storywork. UBC Press.

Bang, M., \& Marin, A. (2015). Nature-culture constructs in science learning: Human/non-human agency and intentionality. Journal of Research in Science Teaching, 52(4), 530-544. https://doi.org/10.1002/tea.21204

Davis, H., \& Todd, Z. (2016). On the importance of a date, or decolonizing the Anthropocenes. ACME: An International Journal for Critical Geographies, 16(4), 761-780.

El-Sherif, L. (2020). Six Nations Land Defenders in Caledonia reveal hypocrisy of Canada's land acknowledgements. The Conversation. https://theconversation.com/ six-nations-land-defenders-in-caledonia-reveal-hypocrisy-of-canadas-land-acknowled gements- 145158 .

Lewis, S. L., \& Maslin, M. A. (2015). Defining the Anthropocene. Nature, 519(7542), 171. https://doi.org/10.1038/naturel4258

Liboiron, M., Tironi, M., \& Calvillo, N. (2018). Toxic politics: Acting in a permanently polluted world. Social studies of science, 48(3), 331-349. https://doi.org/ $10.1177 / 0306312718783087$

McKinley, E. (2001). Cultural diversity: Masking power with innocence. Science Education, 85(1), 74-76.

NASA Science. (2020). Earth. https://solarsystem.nasa.gov/planets/earth/in-depth/

Niro, S., Oneida, K. G., \& Brant, A. (1999). Origin stories - Sky woman. Canadian Museum of History. https://www.historymuseum.ca/cmc/exhibitions/aborig/ $\mathrm{fp} / \mathrm{fpz} 2 \mathrm{f} 22 \mathrm{e} \cdot \mathrm{html}$

TallBear, K. (2013). Native American DNA: Tribal belonging and the false promise of genetic belonging. University of Minnesota Press.

Tuck, E., \& Yang, W. (2012). Decolonization is not a metaphor. Decolonization: Indigeneity, Education \& Society, $1(1), 1-40$. 
Open Access This chapter is licensed under the terms of the Creative Commons Attribution 4.0 International License (http://creativecommons.org/licenses/by/4.0/), which permits use, sharing, adaptation, distribution and reproduction in any medium or format, as long as you give appropriate credit to the original author(s) and the source, provide a link to the Creative Commons license and indicate if changes were made.

The images or other third party material in this chapter are included in the chapter's Creative Commons license, unless indicated otherwise in a credit line to the material. If material is not included in the chapter's Creative Commons license and your intended use is not permitted by statutory regulation or exceeds the permitted use, you will need to obtain permission directly from the copyright holder. 